\title{
A Study of Fear of Death of Teacher Educators
}

\author{
Dr. D.Mohana \\ Associate professor, Education wing,DDE, Annamalaiunjversity.
}

\begin{abstract}
The death is one of the most important matter for man to know more about it was the study. Man has been very curious in finding out the causes and the consequences of the events in this world, all the inventions ,discoveries and the scientific growth and developments are the consequences of man's curiosity to know the occurrence of the events. Hence the this problem was selected for the study.
\end{abstract}

Accepted Date: 24 June 2013

\section{Introduction}

Birth is followed by death not only in the case of human beings, but also in the case of all living creatures. Though death is unavoidable, people attitude fear of their own death to something intra-personal (with in), inter personal (between person) and transportation (beyond personal) as a consequence of mortal nature of man .Individuals have different meanings to their own death .It may reflect the variations in personal and social back grounds. The degree and the intensity of religious beliefs seem to provide deep insight into the manner in which individual's scope with their awareness of death .It is believed that the active commitment of religious belief and practice tends to reduce the severity and the intensity of the manifest or anxiety of death. Most highly religious minded person's belief in the life hereafter. Death comes to main in number of ways. But nobody can predict when a man is going to die. Every living person is thinking that he will live for many years. But no one can escape from death or conquer death. There are mythological stories, we have heard that some persons conquered death by the spiritual power infused in them, and the religious saints who led exceptionally holy life brought back the lives of the dead persons. Thus having applied all the possible scientific appliances and found that all his efforts are useless; man attributes the event of death to something beyond his reach or to some supernatural event. That something supernatural event also is beyond his scope of understanding. Therefore death seems to man a mysterious event which is a battling issue and a problem which can never be resolved and will remain perplexing human race forever.

\subsection{Statement of the problem:}

Death seems to man a mysterious event which is a battling issue and a problem which can never be resolved and will remain perplexing human race forever. Hence, the problem selected for the study may be stated as" A Study Of Fear Of Death Of Teacher Educators In Nagai District"

\subsection{Objectives of the study:}

The following are the objectives of the present study.

1. To study the fear of death of teacher educators in Nagai district.

2. To study the difference if any between the male and female teacher educators in respect of their fear of death.

3. To study the difference if any between the teacher educators age up to 40 years in respect of their fear of death.

4. To study the difference if any between the teacher educators from rural area and urban area in respect of their fear of death.

5. To study the difference if any between the teacher educators working in Government institutions and private institutions in respect of their fear of death.

\subsection{Hypothesis:}

The following are the hypothesis formulated for the present study

1. The fear of death was high in the teacher educators of Nagai District.

2. There is no significant difference between the male and female teacher educators in respect of their fear of death.

3. There is no significant difference between the teacher educators age upto 40 years and above 40 years in respect of their fear of death. 
4. There is no significant difference between the teacher educators from rural areas and urban area in respect of their fear of death.

5. There is no significant difference between the teacher educators working in Government institutions and private institutions in respect of their fear of death.

\subsection{Method of Study:}

In the present study, normative study survey method is adopted.

\subsubsection{The sample:}

Random sampling technique was used in the selection of the sample as many as 220 teacher educators in Nagai District of Tamilnadu,India.

\subsubsection{Tool used for the study}

The fear of personal death scale by Dr. Rajamanickam,M (1999)was used.

Statistical techniques used

To analyze the data descriptive and differential analysis were carried out.

\section{Analysis and interpretation}

The mean scores of fear of death for the total group indicates that teacher educators have high level of fear of death.

Table no:2.1

\begin{tabular}{|c|c|c|c|c|c|}
\hline S.No & \multicolumn{2}{|l|}{ Variables } & $\mathrm{N}$ & Mean & Standard \\
\hline \multirow[t]{2}{*}{1} & \multirow[t]{2}{*}{ Gender } & Male & 101 & 131.16 & 1.35 \\
\hline & & Female & 119 & 131.55 & 1.76 \\
\hline \multirow[t]{2}{*}{2} & \multirow[t]{2}{*}{ Age } & Up to 40 years & 126 & 120.93 & 1.48 \\
\hline & & Above 40 years & 94 & 131.96 & 1.57 \\
\hline \multirow[t]{2}{*}{3} & \multirow[t]{2}{*}{ Locality } & Rural & 167 & 131.67 & 1.59 \\
\hline & & Urban & 53 & 130.42 & 1.47 \\
\hline \multirow[t]{2}{*}{4} & \multirow{2}{*}{$\begin{array}{l}\text { Management } \\
\text { of the } \\
\text { institutions }\end{array}$} & Government & 144 & 131.50 & 2.10 \\
\hline & & Private & 76 & 131.34 & 1.44 \\
\hline
\end{tabular}

Table no:2.2

\begin{tabular}{|c|l|l|l|l|l|l|}
\hline Sample & $\begin{array}{l}\text { Sub- } \\
\text { Sample }\end{array}$ & N & Mean & S.D & $\begin{array}{l}\text { 't' } \\
\text { Value }\end{array}$ & $\begin{array}{l}\text { Level } \\
\text { significance } \\
0.05 \text { level }\end{array}$ \\
\hline Gender & Male & 101 & 131.16 & 1.35 & 1.85 & Not significant \\
\cline { 2 - 5 } & Female & 119 & 131.55 & 1.76 & & \\
\hline
\end{tabular}

Table no:2.3

\begin{tabular}{|c|c|c|c|c|c|c|}
\hline Sample & Sub-Sample & $\mathrm{N}$ & Mean & S.D & $\begin{array}{l}\text { 't' } \\
\text { Value }\end{array}$ & $\begin{array}{l}\text { Level of significance at } \\
0.05 \text { level }\end{array}$ \\
\hline \multirow[t]{2}{*}{ Age } & $\begin{array}{l}\text { Up to } 40 \\
\text { years }\end{array}$ & 126 & 130.93 & 1.48 & \multirow[t]{2}{*}{4.94} & \multirow[t]{2}{*}{ Significant } \\
\hline & $\begin{array}{l}\text { Above } 40 \\
\text { years }\end{array}$ & 94 & 131.96 & 1.57 & & \\
\hline
\end{tabular}

Table no:4

\begin{tabular}{|l|l|l|l|l|l|l|}
\hline Sample & $\begin{array}{l}\text { Sub- } \\
\text { Sample }\end{array}$ & N & Mean & S.D & $\begin{array}{l}\text { 't' } \\
\text { Value }\end{array}$ & $\begin{array}{l}\text { Level } \\
\text { significance of } \\
\text { 0.05 level }\end{array}$ \\
\hline Locality & Rural & 167 & 131.67 & 1.59 & 5.07 & Significant \\
\cline { 2 - 7 } & Urban & 53 & 130.42 & 1.47 & & \\
\hline
\end{tabular}




\begin{tabular}{|c|c|c|c|c|c|c|}
\hline \multicolumn{7}{|c|}{ Table no:5 } \\
\hline Sample & Sub-Sample & $\mathrm{N}$ & Mean & S.D & $\begin{array}{l}\text { 't' } \\
\text { Value }\end{array}$ & $\begin{array}{l}\text { Level of } \\
\text { significance at } \\
0.05 \text { level }\end{array}$ \\
\hline \multirow{2}{*}{$\begin{array}{l}\text { Management } \\
\text { institutions }\end{array}$} & Government & 144 & 131.50 & 2.10 & \multirow[t]{2}{*}{0.49} & \multirow[t]{2}{*}{ Not significant } \\
\hline & Private & 76 & 131.34 & 1.44 & & \\
\hline
\end{tabular}

\section{Interpretation}

The teacher educators of the each of different sub groups are having relatively a high level of fear of death

There is no significant difference between the male and female teacher educators in respect of their fear of death. The ' $t$ ' value is found to be 1.85 which is not significant at 0.05 level. Therefore the null hypothesis is retained and it is concluded that there is no significant difference in fear of death between the male and female teacher educators.[Table:2]

There is no significant difference between the teacher educators age group up to 40 years and above 40 years in respect of their fear of death. The ' $t$ ' value is found to be 4.94 which is significant at 0.05 level .Hence the null hypothesis is rejected. It is inferred that the teacher educators do differ significantly in their fear of death on the basis of their age group. More over the educators of age above 40 years were found to have more fear of death than the teacher educators of age up to 40 years[Table:3]. There is no significant difference in fear of death between the teacher educators from rural area and urban area. The ' $t$ ' value is found to be 5.07 which is significant at 0.05 level .Hence the null hypothesis is rejected. It is inferred that the teacher educators do differ significantly in their fear of death on the basis of locality. More over the teacher educators from rural area have more fear of death than the teacher educators from urban area[Table:4].

There is no significant difference between the teacher educators working in government institutions and private institutions. The ' $t$ ' value is found to be 0.49 which is not significant at 0.05 level. Hence the null hypothesis is retained. It is inferred that teacher educators does not differ significantly in their fear of death on the basis of institutions management type.[Table:5]

\section{Findings of the study}

The fear of death was more according to the sample collected.

There is no significant difference between the teacher educators of male and female and working in government and private institutions in respect of their fear of death. There is a significant difference between the teacher educators age up to 40 years and above 40 years, rural and urban area in respect of their fear of death.

\section{Conclusion}

In the present study the age limit, locality of teacher educators do cause significant difference in respect of their fear of death but the gender, management type of the teacher educators do not cause any significant difference in respect of their fear of death.

\section{References}

[1]. Alken, L.R 1978 The Psychology of later life, Philadelphia: W.B.Saunders Co.

[2]. Broota, K.D and Kaur, A 1992.Super natural Beliefs and Death Anxiety. Master Dissertation, Delhi University

[3]. Charmaz, K 1980 The Social Reality of Death: Reading Mass: Addison Wesley Publishing Company.

[4]. Dempsey, D 1975.The Way We Die, New York: Macmillian Co.

[5]. Freud, S.1920 Beyond the pleasure Principle. Vol.28, The Standard Edition, London. 